\title{
Induction of sprouting on physicochemical profile and bioactive compounds in peach cultivars by foliar applications
}

\author{
Perfil físico-químico y compuestos bioactivos de los frutos de cultivares \\ de durazno, sometidos a la aplicación de inductores de brotación
}

\author{
Rafael Bibiano Ferreira ${ }^{1 *}$, Sarita Leonel ${ }^{1}$, Marcelo de Souza Silva1, Jackson Mirellys Azevêdo Souza1, \\ Ana Carolina Bolfarini ${ }^{1}$, Joyce Helena Modesto ${ }^{1}$, Vitor Hugo Artigiani Filho ${ }^{2}$
}

\begin{abstract}
The induction of sprouting is a fundamental practice to grow temperate fruits in warmer regions, as the use of alternative products are necessary. This study aimed to verify the influence of foliar nitrogen fertilizer application to induce bud sprouting at different doses in three types of peach cultivars, regarding fruit quality, in Botucatu, state of Sao Paulo. This study occurred at the experimental orchard of Botucatu Agriculture School of Universidade Estadual Paulista (FCA/UNESP) in 2015 and 2016. Evaluations consisted of three cultivars Douradão, BRS Kampai and BRS Rubimel; and four doses of foliar nitrogen fertilizer $(0 ; 1.25 ; 2.50$ and $3.75 \%)$ with $4 \%$ calcium nitrate in all treatments. A randomized experimental design was conducted with 12 treatments, 4 replicates and 5 fruits per plot, that is, 240 evaluated fruits in each productive cycle. Fruits produced by cultivar BRS Rubimel showed the highest mean mass among the others, being greater than $100 \mathrm{~g}$, regardless of applied dose. In this study, different doses influenced physical, physicochemical and biochemical attributes of fruits in all cultivars. However, both cultivars showed good quality standards in terms of size, high soluble solids content and low acidity, being recommended for direct consumption in Botucatu, state of Sao Paulo.
\end{abstract}

Keywords: Prunus persica L.; cultural practices; nitrogen foliar fertilizer; Erger; calcium nitrate.

\section{RESUMEN}

La inducción de brotación es una práctica fundamental en el cultivo de frutales en regiones de clima caliente. El objetivo de este trabajo fue evaluar el efecto de productos alternativos con la aplicación de diferentes dosis del fertilizante foliar nitrogenado (FFN), para inducir a la brotación y la calidad de frutos de tres cultivares de durazno en Botucatu - SP. El trabajo fue realizado durante los años 2015 y 2016, en la Estación Experimental de la Facultad de Ciencias Agronómicas de la Universidad Estadual Paulista, campus de Botucatu, SP. Los cultivares evaluados fueron durazno Douradão, BRS Kampai y BRS Rubimel, con cuatro dosis de FFN: 0; 1,25; 2,50 y 3,75\%, asociadas al 4\% de nitrato de calcio. El diseño experimental fue en bloques al azar, con 12 tratamientos, 4 repeticiones y 5 frutos por parcela, totalizando 240 frutos evaluados, en cada ciclo productivo. Los frutos producidos por el cultivar BRS Rubimel presentaron el mayor peso medio de los tres cultivares analizados, y fue superior a $100 \mathrm{~g}$, independientemente de la dosis del FFN utilizada. Las diferentes dosis del FFN utilizadas en este trabajo afectaron las características organolépticas de los frutos de los cultivares evaluados, en aspectos físicos, fisicoquímicos y bioquímicos. Los cultivares BRS Kampai y BRS Rubimel presentaron frutos con patrones óptimos de calidad en cuanto al tamaño, contenido de sólidos solubles y baja acidez, y son recomendados para producción destinada al consumo fresco en la región de Botucatu - SP.

Palabras clave: Prunus persica L., prácticas culturales, fertilizante foliar nitrogenada, nitrato de calcio.

\section{Introduction}

The highlight of the state of São Paulo in the production of peaches occurred in function of advances in genetic improvement research, since enabled to grow peaches in subtropical and tropical regions around the world (Scariotto et al., 2013), through the development of cultivars that requires low demand in cold (Wagner Júnior et al., 2014).

In Brazil, the main peach trees cultivated in mild winter areas were developed by breeding programs of the Agronomic Institute of Campinas

\footnotetext{
1 Department of Horticulture, Universidade Estadual Paulista (UNESP), Botucatu, Brazil.

2 Field Development Manager - Valagro do Brasil Ltda.

* Corresponding author: aprigio_bibiano@hotmail.com
} 
(IAC) and EMBRAPA - Centre for Temperate Climate Agricultural Research. Both institutions have already launched various materials of low demand in cold over the past few years. By AIC, the cultivar Douradão, launched in 1998, is one of the most planted in the state of São Paulo, due to the good yield associated with its excellent fruit quality (Wagner Júnior et al., 2014). Besides that, Embrapa released the cultivars BRS Kampai and BRS Rubimel between 2007 and 2009. (Scaranari et al., 2009).

Fruit quality is an essential factor to produce peaches for direct consumption in the Southeastern region (Araújo, 2008). However, fruits intended for table consumption must have a good proportion of red pulp coloration, high levels of soluble solids, white or yellow pulp; besides being resistant to transport and storage (Wagner Júnior et al., 2014).

Uses of inductors to late sprouting of fructification pruning is of fundamental practice in peach orchards in mild winter areas, since provides both bud and bloom improvements; therefore, allowing a balanced development and vigorous new shoots, besides higher productive plants.

Among the main products used to stimulate sprouting, hydrogenated cyanamide has been reported as being the most effective. Although, it is highly toxic and has been restricted in several international markets (Leonel et al., 2014), which has contributed to search for others compounds that induce bud formation of temperate fruits, such as foliar nitrogen fertilizer (FNF).

The basis of the product consists of mono- \& disaccharides, calcium, nitrogen and diterpenes; providing a stimulation of sprouting by cellular respiration under unfavourable climatic conditions, since their compounds release activate budding metabolism (Valagro, 2013). Positive effects have already been reported in some temperate fruit trees, but not in peach trees.

The induction of sprouting is a fundamental practice to grow temperate fruits in warmer regions, such as the state of São Paulo; but there are few reports in the literature describing the influence of these products on fruit quality produced by plants, which is crucial to fruit market and direct consumption. In this way, this study aimed to verify the influence of foliar nitrogen fertilizer application to induce bud sprouting at different doses in three types of peach cultivars, regarding fruit quality, in Botucatu, state of Sao Paulo.

\section{Material and Methods}

\section{Description of the experimental area and treatments}

This study took place at the experimental orchard of the Department of Horticulture, Botucatu School of Agriculture, Universidade Estadual Paulista (UNESP) in the state of São Paulo.

Botucatu is located at $22^{\circ} 51^{\prime} 55^{\prime \prime} \mathrm{S}, 48^{\circ} 27^{\prime} 22^{\prime \prime}$ $\mathrm{W}$; and an altitude of $810 \mathrm{~m}$. The predominant climate in the region is $\mathrm{Cfa}$, that is, hot temperate (mesothermal), with an average annual temperature of $20.3^{\circ} \mathrm{C}$ (Cunha; Martins, 2009).

The peach cultivars Douradão, BRS Kampai and BRS Rubimel were evaluated within two productive cycles, that is, 2015 and 2016; when plants reached the age of 4 and 5 years old, respectively. All plants grew in a cup system at a spacing of $6.0 \times 4.0 \mathrm{~m}$ and grafted on Okinawa rootstock.

Treatments consisted of three cultivars and four doses of foliar nitrogen fertilizer (FNF), that is, $0 ; 1.25 ; 2.50$ and $3.75 \%$ FNF with $4 \%$ calcium nitrate $(\mathrm{CN})$ in all treatments.

On July 15 , fructification pruning was performed in both cycles. Then, FNF Erger ${ }^{\circledR}$ was immediately applied, such fertilizer contains monosaccharides, polysaccharides, $15 \%$ total nitrogen and $6.5 \%$ calcium oxide; also, is available as soluble powder, which presents low toxicological risks.

\section{Physical characterization of fruits}

Harvesting only happened when fruits reached the minimum value of $10^{\circ} \mathrm{Brix}$. Replicates consisted of five fruits of each treatment that went through the following analyses: mean fruit weight; length and diameter: obtained by measuring fruits longitudinal and transverse diameters.

\section{Physicochemical characterization of fruits}

According to AOAC (2005), the techniques were used for the following characterizations: $\mathrm{pH}$ was obtained from fruit pulp; titratable acidity; soluble solids were determined by reading three pulp drops in digital refractometer, results were expressed as ${ }^{\circ}$ Brix; maturation index: ratio between soluble solids (SS) and titratable acidity (TA). According to the Somogyi-Nelson method (1944), the procedure was followed to determine 
reducing, non-reducing and total sugars, results were expressed as percentage.

\section{Biochemical characterization of fruits}

Total polyphenols content expressed as grams of gallic acid equivalent per 100 grams of extract $(\mathrm{g}$ GAE $100 \mathrm{~g}^{-1}$ ). Samples were prepared by making a clear dispersion of the powder samples in methanol (i.e., $100 \mathrm{mg}$ samples in $2 \mathrm{~mL}$ methanol) by using an ultrasonic bath for 20 minutes. Then, extractants were centrifuged at $10,000 \mathrm{rpm}$ for 20 minat $4^{\circ} \mathrm{C}$; then supernatants were used as samples.

$240 \mu \mathrm{L}$ were collected from supernatant, which reacted with $360 \mu \mathrm{L}$ of Folin (1:1 v/v) for $3 \mathrm{~min}$. After this process, $2400 \mu \mathrm{L}$ of the mixture was added for spectrophotometer reading at $750 \mathrm{~nm}$ after one hour of dark reaction (Swain; Hills, 1959).

From the same supernatant from the previous analysis, antioxidant activity (mg DPPH - Trolox $100 \mathrm{~g}^{-1}$ pulp) was obtained; then, $150 \mu \mathrm{L}$ were collected, and $2850 \mu \mathrm{L}$ of DPPH solution was added. The samples were conditioned in the dark for 40 minutes, then the spectrophotometer readings were taken at $515 \mathrm{~nm}$ (Brand-Willians et al., 1995).

Moreover, flavonoids (mg of rutin $100 \mathrm{~g}^{-1}$ of pulp) were analysed by using $300 \mathrm{mg}$ of fresh sample that was initially weighed and acidified with $4 \mathrm{~mL}$ of $10 \% \mathrm{MeOH}$ solution. The samples were taken to the ultrasonic bath for 30 minat $30^{\circ} \mathrm{C}$. Then, they were centrifuged for 30 minunder $6000 \mathrm{rpm}$ at $5^{\circ} \mathrm{C}$. The supernatants were collected and added 1 $\mathrm{mL}$ aluminium chloride solution. After $50 \mathrm{~min}$ of reaction in the dark, readings were carried out at $425 \mathrm{~nm}$ (Awad et al., 2000).

\section{Experimental design and data analysis}

The experimental design was carried out with randomized block (RBD) in $3 \times 4$ factorial scheme with three cultivars and four FNF doses $(+4 \% \mathrm{CN})$. Four replicates were used with 5 fruits per plot, i.e. 240 evaluated fruits in each cycle. For statistical analysis, considered the means of each treatment during both productive cycles. Data were submitted to analysis of variance and, when significant, the Tukey test for comparison of cultivars; and polynomial regression analysis for NFN doses were performed. All analyses used the Sisvar® software (Ferreira, 2011).

\section{Results and discussion}

\section{Physical characterization of fruits}

There was a significant effect of an interaction between cultivars and NFN for fruit diameter and length. For fruit weight, there was only a significant effect for cultivars. 'BRS Rubimel' presented a mean of $106.04 \mathrm{~g}$; which was higher than the others (Table 1). Matias et al. (2014) found a mean of $87.13 \mathrm{~g}$ for the same cultivar, indicating its good ability in the production of high fruit weight, that is, a desirable trait for direct consumption. According to Scaranari et al. (2009), the cultivar BRS Rubimel has a fruit production capacity of up to $120 \mathrm{~g}$.

'BRS Kampai' and 'Douradão' did not differ significantly for fruit weight, that is, 92.20 and $88.79 \mathrm{~g}$, respectively (Table 1). Analysing different pruning times for peach trees in Botucatu, state of Sao Paulo, Ferraz (2014) obtained the greatest mean of fruit weight for 'BRS Rubimel' $(93.53 \mathrm{~g})$. While 'BRS Kampai' and 'Douradão' obtained a mean of 79.66 and $78.74 \mathrm{~g}$, respectively.

In the absence of product application ( $0.0 \%$ dose), 'BRS Rubimel' produced fruits with the highest mean length of $69.05 \mathrm{~mm}$, which was significantly superior to the 'BRS Kampai' $(65.15 \mathrm{~mm})$ and 'Douradão' (63.59 mm) (Table 2). When induction is used with NFN application $(1.25 \%, 2.50 \%$ and $3.75 \%)$, 'BRS Rubimel' and 'Douradão' presented greater mean values for fruit length, higher that 'BRS Kampai' at all doses.

In the absence of product application (dose 0\%), 'Douradão' fruits obtained a shorter length than 'BRS Rubimel', indicating how important is to induce bud sprouting to improve fruit quality

\footnotetext{
Table 1. Mean fruit weight of three peach cultivars submitted to nitrogen foliar fertilizer and calcium nitrate. Botucatu, 2016.
}

\begin{tabular}{lc}
\hline Cultivar & fruit weight $\mathrm{g}$ \\
\hline Douradão & $88,79 \mathrm{~b}$ \\
BRS Kampai & $91,20 \mathrm{~b}$ \\
BRS Rubimel & $106,04 \mathrm{a}$ \\
CV\% & 7,76 \\
DMS & 6,42 \\
\hline
\end{tabular}

Means followed by the same letter in the column do not differ significantly by Tukey test at $1 \%$ significance. 
(Table 2). Moreover, there was no significant interaction between FNF doses for 'BRS Rubimel', since its fruits had a mean length of $66.65 \mathrm{~mm}$, regardless product dose used.

The fruit length data for 'Douradão' showed a positive linear behaviour, mean fruit length increased according to NFN doses up to the $3.75 \%$, where fruits were obtained with a mean of 65.15 $\mathrm{mm}$. However, 'BRS Kampai' showed a negative quadratic behaviour with a maximum function point at the estimated dose of $2.60 \%$, where fruits were obtained with a mean length of $61.10 \mathrm{~mm}$ (Figure 1A).

In relation to interaction between cultivars and product doses, the largest fruit diameter was found for 'BRS Rubimel', that is, $56.46 \mathrm{~mm}$ in the absence of NFN application (dose 0\%); however, it did not differ significantly from 'BRS Kampai' $(55.73 \mathrm{~mm})$ (Table 2). The lowest value of fruit diameter was found in 'Douradão', $(53.89 \mathrm{~mm})$; but not differing from 'BRS Kampai'.

By using the product dose of $2.50 \%$ and $3.75 \%$, greater diameter values were found for 'BRS Rubimel' with $59.15 \mathrm{~mm}$ and $57.12 \mathrm{~mm}$, respectively (Table 2); highlighting one of the main characteristics of this cultivar to produce fruits of high calibre (Scaranari et al., 2009).

The highest fruit diameter of 'BRS Rubimel' was also observed by Gonçalves et al., (2014), during their studies with different types of pruning, and the highest fruit calibre in relation to the other cultivars analysed occurred independently of the treatments. During 2010, 'BRS Rubimel' fruits had a mean diameter of $60.12 \mathrm{~mm}$, while 'BRS Kampai' fruits obtained mean values of 55.16 $\mathrm{mm}$; therefore, values close to those observed in the current study.
Table 2. Length and Diameter of fruits of three peach cultivars submitted to nitrogen foliar fertilizer and calcium nitrate. Botucatu, 2016.

\begin{tabular}{|c|c|c|c|c|}
\hline \multirow{3}{*}{ Cultivar } & \multicolumn{4}{|c|}{ \% Dose } \\
\hline & 0 & 1.25 & 2.5 & 3.75 \\
\hline & \multicolumn{4}{|c|}{ Length (mm) } \\
\hline Douradão & $63.59 \mathrm{~b}$ & $65.25 \mathrm{a}$ & $65.43 \mathrm{a}$ & $65.91 \mathrm{a}$ \\
\hline BRS Kampai & $65.15 \mathrm{~b}$ & $62.89 \mathrm{~b}$ & $60.40 \mathrm{~b}$ & $62.13 \mathrm{~b}$ \\
\hline BRS Rubimel & $69.06 \mathrm{a}$ & $64.87 \mathrm{ab}$ & $67.52 \mathrm{a}$ & $65.15 \mathrm{a}$ \\
\hline CV \% & \multicolumn{4}{|c|}{9.68} \\
\hline DMS & \multicolumn{4}{|c|}{2.33} \\
\hline \multicolumn{5}{|c|}{ Diameter (mm) } \\
\hline Douradão & $53.89 \mathrm{~b}$ & $55.50 \mathrm{a}$ & $54.85 \mathrm{~b}$ & $54.66 \mathrm{~b}$ \\
\hline BRS Kampai & $55.73 \mathrm{ab}$ & $56.43 \mathrm{a}$ & $53.65 \mathrm{~b}$ & $54.21 \mathrm{~b}$ \\
\hline BRS Rubimel & $56.46 \mathrm{a}$ & $55.29 \mathrm{a}$ & $59.15 \mathrm{a}$ & $57.12 \mathrm{a}$ \\
\hline $\mathrm{CV} \%$ & \multicolumn{4}{|c|}{10.73} \\
\hline DMS & \multicolumn{4}{|c|}{2.21} \\
\hline
\end{tabular}

Means followed by the same letter in the column do not differ significantly by Tukey test at $1 \%$ significance.

According to Raseira et al. (2010), 'BRS Kampai' peach has a fruit production capacity of approximately $60 \mathrm{~mm}$ in diameter, which is close to those observed in the current study, regardless of NFN dose (Table 2). There was no significant effect between doses and cultivars, as 'Douradão', 'BRS Kampai' and 'BRS Rubimel' presented a mean diameter of $54.72 \mathrm{~mm}, 55.01 \mathrm{~mm}$ and $57 \mathrm{~mm}$, respectively.

\section{Fruits physicochemical characterization}

There was no significant interaction between cultivars and NFN doses in none of the
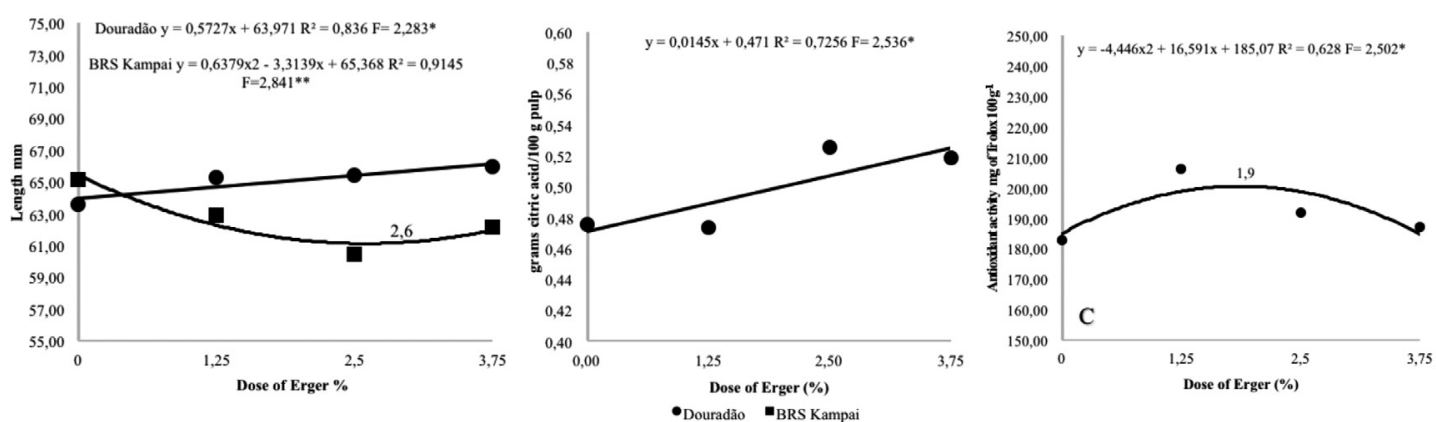

Figure 1. Length, Titratable Acidity and Antioxidant Activity (mg of DPPH $100 \mathrm{~g}^{-1}$ ) in fruits of peach cultivars submitted to nitrogen foliar fertilizer and calcium nitrate. Botucatu, 2019. 
physicochemical variables analysed. However, significant differences were found for the effect of cultivars on the content of soluble solids, $\mathrm{pH}$, titratable acidity, maturation index (MI), nonreducing and total sugar contents of the fruit. However, product doses only presented a significant effect in titratable acidity.

'BRS Kampai' produced fruits with higher soluble solids contents than others, i.e. $15.06^{\circ}$ Brix, which did not differ significantly from 'BRS Rubimel' (14.59 ${ }^{\circ}$ Brix) (Table 3). 'Douradão' did not differ significantly from 'Brs Rubimel', since their fruits had low soluble solids content, i.e. $14.29^{\circ} \mathrm{Brix}$.

Leonel et al., (2011), mentioned the variations in soluble solids levels in peaches of different genotypes during fruit quality assessments in fruits produced in São Manuel, state of Sao Paulo. Moreover, 'BRS Kampai' and 'Brs Rubimel' presented high soluble solids content in this work than those reported by Gonçalves et al., (2014), where same cultivars had 12.26 and $10.95^{\circ}$ Brix in 2009 , respectively.

Nevertheless, climate variations could cause such differences, because is directly involved in plants adaptability and, consequently, in the fruit quality development. There is a positive correlation between soluble solids accumulation in peach fruits at low and high temperature, when fruits are exposed during their growth period in the field (Toralles et al., 2008); thus, intrinsic characteristic for each area. Besides, it could have occurred differences related to fruits maturation stage during evaluation periods.

Table 3. Soluble Solids (SS) and Titratable Total Acidity (AT) contents; $\mathrm{pH}$ and Maturation Index (MI) of fruits of three peach cultivars. Botucatu, 2016.

\begin{tabular}{lcccc}
\hline \multirow{2}{*}{ Cultivar } & $\begin{array}{c}\text { Soluble } \\
\text { Solids }\end{array}$ & $\begin{array}{c}\text { Titratable } \\
\text { Total } \\
\text { Acidity }\end{array}$ & pH & MI \\
\cline { 2 - 4 } & \multicolumn{4}{c}{$\begin{array}{c}\text { g citric } \\
\text { acid/100 } \\
\text { g pulp }\end{array}$} \\
\hline BRS Rubimel & $14.59 \mathrm{ab}$ & $0.43 \mathrm{~b}$ & $4.10 \mathrm{a}$ & $34.58 \mathrm{a}$ \\
BRS Kampai & $15.06 \mathrm{a}$ & $0.55 \mathrm{a}$ & $3.73 \mathrm{~b}$ & $28.39 \mathrm{~b}$ \\
Douradão & $14.29 \mathrm{~b}$ & $0.51 \mathrm{a}$ & $3.90 \mathrm{ab}$ & $28.62 \mathrm{~b}$ \\
\hline CV \% & 8.57 & 16.01 & 13.54 & 21.05 \\
DMS & 0.75 & 0.05 & 0.32 & 3.84 \\
\hline
\end{tabular}

Means followed by the same letter in the column do not differ significantly by Tukey test at $1 \%$ significance.
The fruits 'BRS Kampai' and 'Douradão' presented greater values of TA $(0.55$ and $0.51 \mathrm{~g}$ citric acid/100 g pulp) and lower $\mathrm{pH}$ (3.73 e 3.90), respectively (Table 3 ). The highest acidity in 'BRS Kampai' fruits in relation to 'BRS Rubimel' were also observed by Gonçalves et al., (2014), with no influence of treatment used or the year of assessment, reinforcing the differences between genotypes, regardless of crop condition.

The lowest values of TA and higher $\mathrm{pH}$ values were found in 'BRS Rubimel' fruits, with $0.43 \mathrm{~g}$ of citric acid/100 g of pulp and $\mathrm{pH}$ of 4.10 , not differing from 'Douradão' in $\mathrm{pH}$ (Table 3). Evaluating different varieties of peach in the Southeastern part of the state of Minas Gerais, Brazil; Matias et al. (2014) found acidity of $0.41 \mathrm{~g}$ of citric acid/100 $\mathrm{g}$ of pulp in 'BRS Rubimel' fruits, these results are close to those obtained in the current study.

As described by Kader (1999), the minimum content of SS and the maximum TA recommended for direct consumption of peaches is $10^{\circ} \mathrm{Brix}$ and $0.6 \%$, respectively. Therefore, fitting of data obtained for 'BRS Rubimel', 'BRS Kampai' and 'Douradão' in Botucatu, state of Sao Paulo.

For the isolated effect of NFN doses in TA, there was a positive linear behaviour, since fruit acidity increased when doses increased (Figure 1B). There was a difference of $0.05 \mathrm{~g}$ of citric acid/100 $\mathrm{g}$ of pulp between the highest $(3.75 \%)$ and lower $(0 \%)$ NFN dose used, or $9.79 \%$.

The increase of the TA in peach fruits in function of the application of compounds for overcoming dormancy was also observed by Leonel et al. (2014), as plants treated with hydrogenated cyanamide increased fruit acidity and $\mathrm{pH}$ in comparison to the control. However, there are no reports in the literature regarding the influence of the NFN on these parameters.

According to Giraldi and Rombaldi (2003), weather conditions, maturation stage and fruit position in the plant are within the main factors that influence fruits acidity in a same cultivar. In this way, it is possible that the largest bud sprouting of the plants as a function of increasing doses of NFN has caused a reduction in the incidence of solar radiation in the fruits, providing an increase in acidity.

'BRS Rubimel' had the highest rate of maturation (34.58), due to low acidity obtained in fruits, once soluble solids contents were like those obtained in 'BRS Kampai' (Table 3). With lower values, 
'Douradão' and 'BRS Kampai' fruits presented maturation index of 28.62 and 28.39, respectively.

Similar results were found by Gonçalves et al. (2014) in Pato Branco, state of Parana, where 'BRS Rubimel' and 'BRS Kampai' fruits presented maturation index of 30.99 and 28.36, respectively. In the same study, 'BRS Kampai' fruits presented the highest values of soluble solids $\left(12.26^{\circ} \mathrm{Brix}\right)$, but also associated with a higher TA $(0.43 \%$ citric acid), which reduced its maturation index, as well as observed in the current study.

The fruits of 'BRS Kampai' with $5.71 \%$ NRS and $7.26 \%$ TS; and 'BRS Rubimel' with 5.74\% NRS and $7.09 \% \mathrm{TS}$, achieved the highest levels of reducing and total sugars (Table 4). 'Douradão' presented lower levels, that is, $2.29 \%$ NRS and $5.68 \%$ TS.

The differences in the concentrations of reducing, non-reducing and total sugars are mainly based on genotypic variation among cultivars that was also observed by Lima et al. (2013) in their 16 peaches varieties assessments in Maria da Fé, state of Minas Gerais.

\section{Biochemical characterization of fruits}

There was a significant effect for antioxidant activity and fruits total flavonoids contents. For NFN doses, it was observed a significant effect only for antioxidant activity of fruits. The total polyphenols content in fruits of three cultivars ranged from 422.88 to $442.69 \mathrm{mg}$ gallic acid $100 \mathrm{~g}^{-1}$ of pulp (Table 4)

'BRS Rubimel' fruits had a yellow pulp colour, showed the highest antioxidant activity among

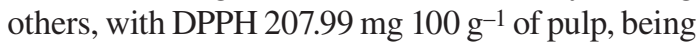
higher to those observed for 'Douradão' (yellow pulp fruits) and 'BRS Kampai' (white pulp fruits), which presented antioxidant activity of 183.87 and 183.74 mg of DPPH $100 \mathrm{~g}^{-1}$ of pulp, respectively (Table 4).
Evaluating the antioxidant activity in fruits of different peach cultivars, Di Vaio et al. (2014), obtained in white pulp fruits values between 4.25 and 4.37 mmol Trolox equivalent $\mathrm{Kg}^{-1}$ of fresh weight, and to yellow pulp fruits between 4.22 and $4.91 \mathrm{mmol}$ Trolox equivalent $\mathrm{Kg}^{-1}$ of fresh weight. According to the same authors, the lack of standardization between methodologies used for conducting this type of analysis is a factor that hinders the comparison between antioxidant activity in foods through data from other studies found in the literature.

Once fruits antioxidant capacity of 'Douradão' and 'BRS Kampai' did not differ among themselves, it is possible to infer no influence of fruit pulp coloration. These results show that the antioxidant capacity of peach fruit is related to each cultivar individual characteristic, regardless of classification group (Gil et al., 2002), which may have to be considered during selection process of new cultivars in breeding programs.

For the isolated effect of NFN doses in fruits antioxidant activity, there was a positive quadratic behaviour with maximum point of the function at the estimated dose of $1.9 \%$, since provided the fruits of three cultivars of DPPH $200.5 \mathrm{mg} 100 \mathrm{~g}^{-1}$ of pulp (Figure 1C). This behaviour can be associated to the fact that the intermediate dose is adequate to bud sprouting, allowing greater balance between reproductive and vegetative structures, besides may have leveraged some qualitative attributes of the fruits during growth and maturation phase.

Although there are no reports in the literature about interference from sprouting inducers application in fruits biochemical characteristics, it is already known that these attributes can be influenced by cultivation conditions, i.e. environmental variables and management techniques adopted (Melo et al., 2006).

Table 4. Reducing sugars (RS), non-reducing sugars (NRS) and total sugars (TS); total polyphenol content, antioxidant activity and flavonoids of fruits of peach cultivars. Botucatu, 2019.

\begin{tabular}{|c|c|c|c|c|c|c|}
\hline \multirow{2}{*}{ Cultivar } & \multicolumn{3}{|c|}{ Sugar contents $\%$} & \multirow{2}{*}{$\begin{array}{l}\text { Polyphenol mg } \\
\text { Gallic ac. } 100 \mathrm{~g}\end{array}$} & \multirow{2}{*}{$\begin{array}{c}\text { Flavonoids } \\
\text { mg Rutin } 100 \mathrm{~g}\end{array}$} & \multirow{2}{*}{$\begin{array}{l}\text { DPPH mg of } \\
\text { Trolox } 100 \mathrm{~g}\end{array}$} \\
\hline & $\mathrm{RS}$ & NRS & TS & & & \\
\hline Douradão & $1.55 \mathrm{a}$ & $4.29 \mathrm{~b}$ & $5.68 \mathrm{~b}$ & $424.11 \mathrm{a}$ & $22.10 \mathrm{a}$ & $183.87 \mathrm{~b}$ \\
\hline BRS Kampai & $1.65 \mathrm{a}$ & $5.71 \mathrm{a}$ & $7.26 \mathrm{a}$ & $422.88 \mathrm{a}$ & $17.76 \mathrm{~b}$ & $183.74 \mathrm{~b}$ \\
\hline BRS Rubimel & $1.67 \mathrm{a}$ & $5.74 \mathrm{a}$ & $7.09 \mathrm{a}$ & 442.69 a & $25.21 \mathrm{a}$ & 207.99 a \\
\hline $\mathrm{CV} \%$ & 15.84 & 13.89 & 12.02 & 12.77 & 21.84 & 10.03 \\
\hline DMS & 0.44 & 0.62 & 0.68 & 47.63 & 4.11 & 4.81 \\
\hline
\end{tabular}

Means followed by the same letter in the column do not differ significantly by Tukey test at $1 \%$ significance. 
'BRS Rubimel' and 'Douradão', which are yellow pulp cultivars, had high flavonoids content, such as 25.21 and $22.10 \mathrm{mg}$ rutin on $100 \mathrm{~g}^{-1}$ of pulp, respectively. While 'BRS Kampai' had a mean of $17.76 \mathrm{mg}$ rutin on $100 \mathrm{~g}^{-1}$ pulp. These values are below those found by Di Vaio et al. (2014), who obtained between 32.78 to $80.92 \mathrm{~g}$ of quercetin equivalent $\mathrm{Kg}^{-1}$ of fresh weight for different peach and nectarine cultivars. The same authors did not observe any relationship between fruit pulp colour and high flavonoid contents. Evidencing that the biochemical characteristics analysed varies depending on both species and cultivar.

The flavonoids are a class of phenolic compounds with antioxidant activity involved in several physiological functions in plants, such as cell elongation, protection against ultraviolet radiation, attraction of insect pollinators, resistance to diseases and the colouring of various plants structures, such as flowers and fruits (Fagan et al., 2015).

The current study's data indicate that the different NFN doses used to overcome dormancy of peaches in Botucatu, state of Sao Paulo, may interfere in the physical, physicochemical and biochemical quality of the fruits. However, the fruits of three assessed cultivars showed great quality, as the size, high sugar content, low acidity and excellent biochemical quality for direct consumption in the state of São Paulo.

\section{Conclusions}

The fruits produced by 'BRS Rubimel' showed mean mass exceeding $100 \mathrm{~g}$ associated to a high antioxidant activity, regardless of the NFN dose applied.

There was interference of NFN doses applied in physical and physicochemical characteristics of three cultivars. However, all of them showed fruits in optimum standards of quality, as size, high content of soluble solids, low acidity being recommended to be produced for direct consumption in the region of Botucatu, state of Sao Paulo.

There was no influence for biochemical characteristics in pulp colour in any cultivars, but 'BRS Rubimel' fruits showed the highest antioxidant activity associated with high flavonoids contents, that is, an interesting qualitative attribute for this fruit consumption in the state of São Paulo.

\section{Acknowledgments}

The authors would thank to National Council for Scientific and Technological Development (CNPq) and the Coordination for the Improvement of Higher Education Personnel (CAPES) to scholarship granted for the studies.

To the VALAGRO company, especially to Mr. Vitor Hugo Artigiani Filho, for supporting me during the experiment execution.

\section{Literature cited}

AOAC.

2005. Official methods of analysis of the Association of Oficial Analitycal Chemistry International. 18th ed. Gaithersburg, US. 1015 p.

Araújo, J.P.C.; Rodrigues, A.; Scarpare Filho, J.A.; Pio, R. 2008. Influência da poda de renovação e controle da ferrugem nas reservas de carboidratos e produção de pessegueiro precoce. Revista Brasileira de Fruticultura, 30: 331-335

Awad, A.M.; Jager, A.; Westing, L.M. Van.

2000. Flavonoid and chlorogenic acid levels in apple fruit: characterization of variation. Scientia Horticulturae, 83(3): 249-263.

Brand-Willians, W.; Cuvelier, M.E.; Berset, C. 1995. Use of a free radical method to evaluate antioxidant activity. LWT-Food Science and Tecnology, 28: 25-30.

Cunha, A.R.; Martins, D.

2009. Classificação climática para os municípios de Botucatu e São Manuel, SP. Irriga, 14: 1-11.

Di Vaio, C.; Marallo, N.; Graziani, G.; Ritieni, A.; Di Matteo, A. 2014. Evaluation of fruit quality, bioactive compounds and total antioxidant activity of flat peach cultivars. Journal of the Science of Food and Agriculture, 10:1-8.
Fagan, E.B.; Ono, E.O.; Rodrigues, J.D.; Chalfun Júnior, A.; Dourado Neto, D.

2015. Fisiologia Vegetal: Reguladores Vegetais. Organização Andrei Editora. 300 p.

Ferraz, R.A.

2014. Avaliação de cultivares e épocas de poda para o pessegueiro na região de Botucatu/SP. Universidade Estadual Paulista Júlio de Mesquita Filho, Faculdade de Ciências Agronômicas, Botucatu, 79 p.

Ferreira, D.F.

2011. Sisvar: A computer statistical analysis system. Ciência e Agrotecnologia, 35(6): 1039-1042.

Gil, M.I.; Tomas-Barberan, F.A.; Hess-Pierce, B.; Kader, A.A. 2002. Antioxidant capacities, phenolic compounds, carotenoids, and vitamin $\mathrm{C}$ contents of nectarine, peach, and plum cultivars from California. Journal of Agricultural and Food Chemistry, 50(17): 4976-4982.

Girardi, C.; Rombaldi, C.V.

2003.Desenvolvimento e maturação de pêssegos. In: Protas, J.F.S.; Madail, J.C.M (Eds.). Sistema de produção de pêssego de mesa na Região da Serra Gaúcha. Sistema de Produção, 3. Bento Gonçalves: EMBRAPA Uva e 
Vinho, 2003. (Versão eletrônica). Available: <http:// sistemasdeproducao.cnptia.embrapa.br/FontesHTML/ Pessego/PessegodeMesaRegiaoSerraGaucha/index.htm>. Consulted: 15/dic/2016.

Gonçalves, M.A.; Picolotto, L.; Azevedo, F.Q.; Cocco, C.; Antunes, L.E.C.

2014. Qualidade de fruto e produtividade de pessegueiros submetidos a diferentes épocas de poda. Ciência Rural, 44(8): 1334-1340.

Kader, A.A.

1999. Fruit maturity, ripening, and quality relationships. Acta Horticulturae, Leuven, 485: 203-208.

Leonel, S.; Pierozzi, C.G.; Tecchio, M.A.

2011. Produção e Qualidade dos Frutos de Pessegueiro e Nectarineira em Clima Subtropical do Estado de São Paulo. Revista Brasileira de Fruticultura. Jaboticabal - SP, 33(1): 118-128.

Leonel, S.; Leonel, M.; Tecchio, M.A.

2014. Fruit quality in the peach and nectarine with application of hydrogenated cyanamide and mineral oil. Revista Ciência Agronômica, 45(3): 581-587.

Lima, A.J.B.; Alvarenga, A.A.; Malta, M.R.; Gebert, D.; Lima, E.B.

2013. Chemical evaluation and effect of bagging new peach varieties introduced in southern Minas Gerais - Brazil. Food Science and Technology, 33(3): 434-440.

Melo, E.A.; Maciel, M.I.S.; Lima, V.L.A.G.; Leal, F.L.L.; Caetano, A.C.S.; Nascimento, R.J.

2006. Capacidade antioxidante de hortaliças usualmente consumidas. Ciência Tecnologia de Alimentos, 26(3): 639-644.
Matias, R.G.P.; Silva, D.F.P.; Ribeiro, M.R.; Silva, J.O.C.; Oliveira, S.P.; Bruckner, C.H.

2014. Características de frutos de pessegueiros cultivados na Zona da Mata de Minas Gerais. Ciência Rural, Santa Maria, 44(6): 971-974.

Nelson, N.

1944. Aphotometric adaptation of somogi method for determination of glicose. Journal Biological Chemistry, Baltimore, 153: 375-380.

Raseira, M.D.C.B.; Nakasu, B.H.; Ueno, B.; Scaranari, C. Pessegueiro: Cultivar BRS Kampai. Revista Brasileira de Fruticultura, Jaboticabal, 32(4): 1275-1278.

Scaranari, C.F; Rasera, M.D.C.B.; Barbosa, W.; Feldberg, N. P.; Martins, F.P.

2009. Catálogo de cultivares de pêssego e nectarina. Embrapa Clima Temperado. Pelotas, Brazil. 139 p.

Scariotto, S.; Citadin, I.; Raseira, M.C.B.; Sachet, M.R.; Penso, G.A. 2013. Adaptability and stability of 34 peach genotypes for leafing under Brazilian subtropical conditions. Scientia Horticulturae, 155: 111-117.

Toralles, R.P.; Vendruscolo, J.L.; Malgarim, B.M.; Cantilhano, R.F.; Schunemann, A.P.P.; Antunes, P.L.

2008. Características físicas e químicas de cultivares brasileiras de pêssegos em duas safras. Revista Brasileira de Agrociência, 14(2): -338.

VALAGRO. Erger: o disjuntor de gemas. Atessa, 2010. Available: <http://www.valagro.com/ru/farm/products/ valagro/specialties/erger?func $=$ viewThingData; thingId $=$ uYISX0GSrv3tQuGmJdHSQ; thingDataId=1z44gK_jBr3_ g90qWieuMw>. Consulted: 26/set/2018.

Wagner Júnior, A.; Bruckner, C.H.; Pio, R.; Citadin, I.

2014. Cultivo do pessegueiro. In: Pio, R. (Ed.). Cultivo de Fruteiras de Clima Temperado em Regiões Subtropicais e Tropicais. Editora Ufla. Lavras, Brazil. 2014. 652. 